\title{
Joanna Omieciuch
}

Wyższa Szkoła Finansów i Zarządzania w Białymstoku

e-mail: jjom@poczta.onet.pl

\section{JAKOŚĆ I BEZPIECZEŃSTWO ŻYWNOŚCI W POLSCE FOOD QUALITY AND SAFETY IN POLAND}

DOI: $10.15611 /$ sie.2016.2.09

JEL Classification: D12, D18

Streszczenie: Celem artykułu była ocena poziomu jakości i bezpieczeństwa żywności w Polsce w ostatnich kilkunastu latach. Panuje powszechne przekonanie o wysokiej jakości polskiej żywności. Inni badacze twierdzą, że wysoka jakość dotyczy niewielkiej części sektora żywnościowego (produkty tradycyjne, regionalne, ekologiczne). Część autorów twierdzi, że aktualnie na rynku żywności mamy do czynienia z problemem systematycznego pogarszania się jakości żywności, a o tym świadczą choćby różnego rodzaju ,afery żywnościowe” i proceder jej fałszowania. Przeprowadzona analiza wykazała, że trudno jednoznacznie ocenić poziom jakości i bezpieczeństwa żywności w Polsce. W opracowaniu wykorzystano analizę literatury badanego przedmiotu, w tym licznych, wybranych sprawozdań i raportów pokontrolnych różnych organizacji badających jakość i bezpieczeństwo żywności w Polsce, m.in. Państwowej Inspekcji Sanitarnej, Najwyższej Izby Kontroli, Inspekcji Handlowej. W artykule zaprezentowano wybrane zagadnienia, bo obszerność zagadnienia nie pozwoliła zająć się wszystkimi aspektami jakości i bezpieczeństwa żywności.

Słowa kluczowe: jakość, bezpieczeństwo, żywność.

Summary: The aim of the article is an attempt to answer the question whether in the last dozen years, the level of food quality and food safety in Poland has improved or perhaps deteriorated. There is a common belief in the high quality of Polish food. Other researchers find that high quality applies to a small part of the food sector (traditional, regional, and organic products). Some authors say that on the food market we have to deal with the problem of systematic deterioration of the food quality. This is evidenced by even a different kind of "food scandals" and the counterfeiting of food. The analysis showed that it was difficult to clearly assess the level of food quality and food safety. The author uses the typical economic test method in this study. The author analyzed literature of the subject, including many selected reports and audit reports of various organizations which examined food quality and food safety in Poland. The paper presents selected issues, because the extensiveness of the topic does not allow to deal with all aspects of food quality and food safety.

Keywords: quality, safety, food. 


\section{Wstęp}

Konsumpcja jest naturalnym i ostatecznym celem społecznego gospodarowania. W polskim funduszu spożycia znaczny udział stanowi konsumpcja żywności. Jej 25-procentowy udział znajduje swój wyraz nawet w nazwie takiego modelu konsumpcji, używa się bowiem określenia ,żywnościowy model konsumpcji”. Kupując żywność, konsumenci kierują się różnymi przesłankami. Na równi z ceną traktują oni jakość i bezpieczeństwo żywności jako czynnik, który decyduje o zakupie produktów żywnościowych.

Odnośnie do poziomu jakości i bezpieczeństwa żywności w literaturze przedmiotu można spotkać różne oceny tej cechy. Panuje powszechne przekonanie o wysokiej jakości polskiej żywności, o czym można przeczytać w różnych publikacjach ${ }^{1}$. Inni badacze stwierdzają, że wysoka jakość produktów żywnościowych, które nie zawierają szkodliwych składników, dotyczy niewielkiej części sektora żywnościowego (produkty tradycyjne, regionalne, ekologiczne) [Staniak 2014, s. 29]. Część autorów twierdzi, że aktualnie na rynku żywności mamy do czynienia z problemem systematycznego pogarszania się jakości żywności, a o tym świadczą choćby różnego rodzaju ,afery żywnościowe” i proceder fałszowania żywności².

Celem artykułu jest ocena poziomu jakości i bezpieczeństwa żywności w Polsce w ostatnich kilkunastu latach. Autorka artykułu podjęła próbę odpowiedzi na pytanie, czy w ostatnich kilkunastu latach poziom jakości i bezpieczeństwa żywności w Polsce się poprawił, czy też może te istotne atrybuty żywności się pogarszają. W tekście zaprezentowano wybrane zagadnienia, wszak obszerność tematu nie pozwala zająć się wszystkimi aspektami jakości i bezpieczeństwa żywności. W opracowaniu zostanie wykorzystana typowa dla nauk ekonomicznych metoda badawcza, tj. analiza literatury badanego przedmiotu, w tym licznych, wybranych sprawozdań i raportów pokontrolnych różnych organizacji badających jakość i bezpieczeństwo żywności w Polsce, m.in. Państwowej Inspekcji Sanitarnej, Najwyższej Izby Kontroli, Inspekcji Handlowej.

\section{Pojęcie jakości i bezpieczeństwa żywności}

Żywność jest szczególnym rodzajem dobra, bo zaspokaja ono najbardziej podstawowe potrzeby biologiczne gospodarstw domowych. Aktualnie większość konsumentów ma dostęp do wystarczającej ilości produktów żywnościowych. Wzrastają zaś wymagania nabywców co do poziomu ich jakości i bezpieczeństwa. Powszechnie uważa się, że niewłaściwe jedzenie, w tym spożywanie niskiej jakości żywności, jest przyczyną wielu rodzajów chorób powstających zarówno na tle niedoborów niektórych składników odżywczych, jak i ich nadmiaru w codziennej diecie. Szacuje się,

\footnotetext{
${ }^{1}$ Na przykład [Wierzejska 2015, s. 2-6].

2 Na przykład [Majchrzak 2013, s. 6-8].
} 
że w Polsce $20 \%$ populacji cierpi na choroby i odchylenia stanu zdrowia związane z nieprawidłową dietą. Natomiast w skali świata około $19 \%$ zgonów jest wynikiem sześciu czynników ryzyka powiązanych z dietą [Cianciara 2011, s. 21].

Współcześni konsumenci - w literaturze jest wiele badań, które to potwierdzają - cenią sobie wysoką jakość żywności i biorą ją pod uwagę, gdy kupują produkty żywnościowe ${ }^{3}$. Mając zaufanie do produktu i przeświadczenie, że jego jakość jest wysoka, nabywają go. Zapewnienie konsumentom wysokiego poziomu jakości i bezpieczeństwa żywności w całym łańcuchu żywnościowym „od pola do stołu” powinno stać się priorytetem $\mathrm{w}$ działaniach podmiotów gospodarczych na rynku żywnościowym, bo wysoka jakość produktów żywnościowych jest głównym czynnikiem konkurencyjności sektora żywnościowego. Brak odpowiedniej jakości czy też niezapewnienie bezpieczeństwa żywności może doprowadzić przedsiębiorstwa do znacznych spadków przychodów, a nawet do bankructwa.

Jakość jest ważną cechą wyróżniającą produkt, nie dziwi zatem fakt, że współcześnie wzrosło zainteresowanie problemem jakości wśród zarówno konsumentów, jak i producentów. Jakość i bezpieczeństwo żywności to pojęcia bardzo złożone, a sposób ich pojmowania zawiera wiele składowych, które obrazują ewolucję rozumienia tych pojęć w stosunku do żywności ${ }^{4}$. Należy zgodzić się z opinią S. Żakowskiej-Biemans, że ewolucja pojęcia ,jakość żywności” w opinii konsumentów przejawia się $\mathrm{W}$ kwestionowaniu współczesnych, intensywnych metod produkcji i poszukiwaniu żywności pochodzącej z pozytywnie odbieranych systemów produkcji [Ozimek 2007, s. 50].

Powszechnie przez jakość żywności rozumie się jakość zdrowotną, która zależy od zawartych w niej składników odżywczych oraz od obecności w niej substancji obcych, które mogą być szkodliwe dla zdrowia człowieka. W polskim prawie żywnościowym nadal obowiązuje definicja jakości handlowej artykułu rolno-spożywczego. Zgodnie z ustawą o jakości handlowej artykułów rolno-spożywczych z roku 2000 (Dz.U. nr 5, poz. 44), ,jakość handlowa oznacza cechy artykułu rolno-spożywczego dotyczące jego właściwości organoleptycznych, fizykochemicznych i mikrobiologicznych w zakresie technologii produkcji, wielkości lub masy oraz wymagania wynikające ze sposobu produkcji, opakowania, prezentacji i oznakowania nie objęte przepisami sanitarnymi, weterynaryjnymi i fitosanitarnymi” [Gulbicka 2008, s. 47-49].

Badania I. Ozimek wykazały, że współczesne pojmowanie jakości żywności przez konsumentów w największym stopniu należy łączyć z cechami decydującymi o atrakcyjności sensorycznej oraz walorami zdrowotnymi [Ozimek 2007, s. 52].

Tym, co determinuje poziom jakości, nie zapominając o systemach zapewniania jakości (GHP, GMP, HACCP), które stanowią element kontroli wewnętrznej jakości, są głównie państwowe regulacje prawne i instytucje chroniące normy jakościowe

\footnotetext{
${ }^{3}$ Na przykład [Zalega 2012, s. 40-53; Kowrygo, Rejman, Drozdowska 2015, s. 209-221].

${ }^{4}$ Szerzej [Ozimek 2007, s. 47-53; Juchniewicz 2008, s. 101-119].
} 
żywności przed ich naruszeniem w związku z produkcją i handlem artykułami żywnościowymi.

W Polsce już w roku 1928 funkcjonowało Rozporządzenie Prezydenta Rzeczypospolitej z dnia 22 marca 1928 r. o dozorze nad artykułami żywności i przedmiotami użytku [Rozporządzenie Prezydenta Rzeczypospolitej z dnia 22 marca 1928 r. ...]. Rozporządzenie z mocą ustawy, z uwzględnieniem późniejszych zmian, obowiązywało do roku 1971. Drugiego listopada 1970 r. została uchwalona ustawa o warunkach zdrowotnych żywności i żywienia (Dz.U. nr 29, poz. 245), do której wprowadzono poprawki z dniem 6 listopada 1992 r. (Dz.U. nr 91, poz. 456 z 1992 r.). Przed wejściem do UE producenci byli zobligowani do stosowania Polskich Norm (Znak PN). Wraz z akcesją Polski do UE zaczęło obowiązywać prawo wspólnotowe, które zniosło obligatoryjność stosowania znaku PN i norm branżowych. W kolejnych latach członkostwa Polski w UE zbiór aktów prawnych sukcesywnie się poszerzał.

W Polsce według Ustawy o bezpieczeństwie żywności i żywienia z dnia 25 sierpnia 2006 r. (Dz.U. nr 171, poz. 1225) bezpieczeństwo żywności to ogół warunków, które muszą być spełnione, dotyczących w szczególności stosowanych substancji dodatkowych i aromatów, poziomów substancji zanieczyszczających, pozostałości pestycydów, warunków napromieniowania żywności, cech organoleptycznych i działań, które muszą być podejmowane na wszystkich etapach produkcji lub obrotu żywnością w celu zapewnienia zdrowia i życia człowieka. Przed wprowadzeniem ustawy z 25 sierpnia 2006 r. obowiązywało w polskim prawie pojęcie jakości zdrowotnej. Od 2006 r. pojęcie ,jakość zdrowotna” zastąpiono rozszerzonym pojęciem - „bezpieczeństwo żywności” [Gulbicka 2008, s. 50].

W celu weryfikacji przestrzegania przepisów prawnych żywność poddawana jest stałej urzędowej kontroli. W Polsce zewnętrzną kontrolę stosuje pięć inspekcji na mocy odpowiednich przepisów prawnych. Są to Państwowa Inspekcja Sanitarna (PIS), Inspekcja Weterynaryjna (IW), Inspekcja Jakości Handlowej Artykułów Rolno-Spożywczych (IJHARS), Państwowa Inspekcja Ochrony Roślin i Nasiennictwa (PIORiN) oraz Inspekcja Handlowa (IH). Kontrole wykonywane przez te inspekcje są istotnym elementem gwarantowania jakości i bezpieczeństwa żywności.

W Polsce obowiązuje rozproszony model nadzoru nad jakością i bezpieczeństwem żywności, co według wielu badaczy powoduje różne problemy z jego koordynacją i skutecznością. Ma się to wkrótce zmienić. Reforma, nad którą toczą się prace w Ministerstwie Rolnictwa i Rozwoju Wsi, doprowadzi do skonsolidowania nadzoru nad bezpieczeństwem żywności. Od 1 stycznia 2018 r. będzie funkcjonować jedna instytucja: Państwowa Inspekcja Bezpieczeństwa Żywności (PIBŻ). W większości państw członkowskich UE (w 23 spośród 28 krajów) proces konsolidacji instytucji nadzorujących bezpieczeństwo żywności odbył się w ostatnich kilkunastu latach. Twórcy reformy przewidują, że nowa inspekcja uzyska większą efektywność operacyjną, co przyniesie pozytywne efekty dla całej polskiej gospodarki [MRiRW 2016]. 


\section{Poziom jakości i bezpieczeństwa żywności w Polsce}

Stan higieniczno-sanitarny zakładów produkcji i obrotu żywnością kontrolowany przez PIS poprawił się znacznie. Od 2006 r. średnio tylko 2\% obiektów nadzorowanych przez PIS nie spełniało wymagań sanitarnych (tab. 1).

Tabela 1. Odsetek obiektów przemysłowych w sektorze żywności i żywienia nadzorowanych przez PIS niespełniających wymagań sanitarnych w latach 2001-2015

\begin{tabular}{|c|c|c|c|c|c|c|c|c|c|c|c|c|c|c|c|}
\hline Rok & 2001 & 2002 & 2003 & 2004 & 2005 & 2006 & 2007 & 2008 & 2009 & 2010 & 2011 & 2012 & 2013 & 2014 & 2015 \\
\hline$\%$ & 14,5 & 12,4 & 10,2 & 8,6 & 2,9 & 2,3 & 2,3 & 2,3 & 2,2 & 2,1 & 2,0 & 1,7 & 1,7 & 1,7 & 1,9 \\
\hline
\end{tabular}

Źródło: opracowanie własne na podstawie [Stan sanitarny kraju 2007, 2008, s. 99; Stan sanitarny kraju w roku 2015, 2016, s. 15].

Poprawa ta jest efektem systematycznie wdrażanych przez sektor żywnościowy systemów zapewniania jakości oraz modernizacji obiektów przetwórstwa żywności5. Systemy te jeszcze nie zostały wdrożone we wszystkich obiektach, dlatego PIS w pokontrolnym sprawozdaniu z 2015 r. ustalił, że w ,celu zapewnienia właściwego poziomu bezpieczeństwa zdrowotnego żywności należy kontynuować nadzór sanitarny szczególnie w zakresie: wdrażania i skutecznego stosowania systemów kontroli wewnętrznej w obiektach żywności i żywienia - zasad dobrej praktyki higienicznej (GHP), dobrej praktyki produkcyjnej (GMP) oraz systemu HACCP (wraz z niezbędną dokumentacją)" [Stan sanitarny kraju w roku 2015, 2016, s. 45].

W Polsce od roku 2001 istotnie zmniejszył się odsetek kwestionowanych próbek, co jest odzwierciedleniem poprawy stanu sanitarnego obiektów. Świadczy to o poprawie jakości zdrowotnej żywności. Nadal jednak około 3-4\% próbek jest kwestionowanych, bo nie spełnia wymagań prawa żywnościowego (tab. 2).

W powszechnej świadomości funkcjonuje przeświadczenie o wysokiej jakości polskiej żywności. Ta opinia odnosi się do większości produktów ekologicznych, tradycyjnych, regionalnych i lokalnych ${ }^{6}$. Ich wysoka jakość wynika z surowych norm ich produkcji narzucanych przez regulacje prawne. Wysoką ich jakość wykazują badania różnych instytucji zajmujących się urzędową kontrolą tego rodzaju żywności. Na przykład z badań kontrolnych, które przeprowadziła Najwyższa Izba Kontroli w gospodarstwach ekologicznych w latach 2005-2009, wynikło, że na 712 próbek artykułów rolno-spożywczych tylko 4 próbki wzbudziły zastrzeżenia kontrolerów [NIK o rolnictwie... 2010].

Również jakość mikrobiologiczna żywności w Polsce znacznie się poprawiła, o czym świadczy malejąca liczba zatruć pokarmowych (tab. 3).

${ }^{5}$ Stopień wdrażania obligatoryjnych i nieobligatoryjnych systemów zapewnienia jakości analizowała m.in. [Morkis 2014, s. 366-370].

${ }^{6}$ Zestawienie badań wykazujących na lepsze parametry jakościowe żywności ekologicznej w porównaniu z żywnością konwencjonalną w: [Staniak 2014, s. 29]. 
Tabela 2. Środki spożywcze poddane analizie organów PIS w latach 2001-2015

\begin{tabular}{|c|c|c|}
\hline Rok & Liczba próbek zbadanych & Odsetek zakwestionowanych próbek (w \%) \\
\hline 2001 & 346034 & 9,4 \\
\hline 2002 & 312972 & 8,5 \\
\hline 2003 & 205234 & 7,5 \\
\hline 2004 & 134390 & 5,8 \\
\hline 2005 & 96114 & 5,1 \\
\hline 2006 & 92118 & 4,0 \\
\hline 2007 & 99657 & 3,3 \\
\hline 2008 & 76247 & 3,69 \\
\hline 2009 & 77153 & 3,84 \\
\hline 2010 & 66913 & 3,56 \\
\hline 2011 & 70075 & 3,0 \\
\hline 2012 & 67665 & 4,02 \\
\hline 2013 & 67036 & 2,89 \\
\hline 2014 & 69779 & 2,96 \\
\hline 2015 & 70611 & 2,7 \\
\hline
\end{tabular}

Źródło: opracowanie własne na podstawie [Stan sanitarny kraju 2007, 2008, s. 105; Stan sanitarny kraju za 2009, 2010, s. 115; Stan sanitarny kraju w roku 2015, 2016, s. 21].

Tabela 3. Bakteryjne zatrucia pokarmowe w Polsce w latach 2005-2014

\begin{tabular}{|c|c|c|c|c|c|}
\hline \multirow{2}{*}{ Rok } & \multirow{2}{*}{$\begin{array}{c}\text { Bakteryjne zatrucia } \\
\text { pokarmowe }- \\
\text { ogółem }\end{array}$} & \multicolumn{4}{|c|}{ W tym spowodowane przez } \\
\cline { 3 - 6 } & 20065 & 15621 & 658 & 28 & \multirow{2}{*}{ Salmonella } \\
& gronkowce & jad kiełbasiany & Campylobacter \\
\hline 2005 & 17264 & 13216 & 417 & 50 & 47 \\
\hline 2006 & 15241 & 11566 & 407 & 48 & 154 \\
\hline 2007 & 12215 & 9473 & 202 & 46 & 270 \\
\hline 2008 & 10817 & 8847 & 146 & 31 & 360 \\
\hline 2009 & 11464 & 9549 & 217 & 32 & 375 \\
\hline 2010 & 10847 & 8652 & 283 & 35 & 354 \\
\hline 2011 & 10231 & 8444 & 147 & 22 & 431 \\
\hline 2012 & 9053 & 7407 & 128 & 24 & 552 \\
\hline 2013 & 9740 & 8206 & 68 & 29 & 654 \\
\hline 2014 & & & & & \\
\hline
\end{tabular}

Źródło: [Stan sanitarny kraju w roku 2014, 2015, s. 15-16].

Również badania na obecność szkodliwych substancji chemicznych w żywności wykazały, że niedozwolone substancje wykryto wyłącznie w pojedynczych przypadkach, a zbadano ponad 30 tys. próbek [Bezpieczeństwo... 2015]. Z kolei kontrole IW w 2013 r. wykazały, że na blisko 30 tys. badań stwierdzone nieprawidłowości stanowiły zaledwie 0,25\% [Racje i emocje... 2015]. 
Ogólne wrażenie odnośnie do jakości i bezpieczeństwa żywności jest korzystne, bo z zaprezentowanych danych wynika, że poprawia się ich poziom. M. Posobkiewicz, Główny Inspektor Sanitarny, stwierdzając: „,z roku na rok następuje poprawa sanitarna w kontrolowanych obiektach”, dodał: ,ale wciąż nie w takim stopniu, jakiego byśmy sobie życzyli. Jeszcze zbyt mało przedsiębiorców pamięta o podstawowej zasadzie wynikającej z przepisów prawa żywnościowego, a mianowicie, że odpowiedzialność za bezpieczeństwo żywności ponosi przedsiębiorca działający na rynku spożywczym" [Jakość polskiej żywności... 2014, s. 8].

\section{Przejawy pogarszania się jakości i bezpieczeństwa żywności w Polsce}

Problemem, który zauważalny jest od zawsze i nie widać wyraźnego jego rozwiązania, jest systematyczny spadek jakości dóbr żywnościowych w opinii konsumentów. $\mathrm{Z}$ pozoru wszystko jest $\mathrm{w}$ porządku, bo różne kontrole wykazują, że produkty są bezpieczne dla konsumentów - tylko niewielki odsetek badanych próbek budzi zastrzeżenia urzędowych kontrolerów żywności - to i tak ostatnimi czasy w przypadku żywności konwencjonalnej nastąpił duży spadek zaufania do tej żywności. Zwracają na to uwagę na przykład M. Jeżewska-Zychowicz, E. Babicz-Zielińska, W. Laskowski z SGGW [Jeżewska-Zychowicz, Babicz-Zielińska, Laskowski 2009, s. 67].

Żywność produkowana na masową skalę ma często gorsze parametry jakościowe. W literaturze przedmiotu pojawiają się uwagi, że brakuje spójnej teorii objaśniającej ten groźny mechanizm [Meredyk 2014, s. 7-9]. Niejednokrotnie konsumenci wyrażają opinie, że pogorszyła się jakość żywności [Ćwiek 2013]. Dostrzega się to, czytając wypowiedzi na różnych portalach internetowych, gdy „wybuchnie afera żywnościowa" lub zostanie opublikowana informacja o przypadkach niskiej jakości czy o fałszowaniu żywności. Kolejne „afery żywnościowe”, które konsumenci śledzą w mediach, ten spadek zaufania potęgują. R. Wierzejska zestawiła najbardziej nagłośnione - w środkach masowego przekazu - przypadki naruszenia jakości zdrowotnej żywności w latach 2008-2014 (tab. 4).

Badania realizowane przez I. Ozimek w 2007 r. wykazały, że 54\% ankietowanych oceniło jakość żywności oferowanej w sprzedaży w Polsce jako przeciętną (,ani wysoko, ani nisko") , 9\% - bardzo nisko i nisko, 37\% - wysoko i bardzo wysoko [Ozimek 2007, s. 52].

Kontrole IJHARS wykazały, że zwiększyła się liczba nieprawidłowości w latach 2010-2012. Badania prowadzone przez A. Piwowara z UE we Wrocławiu wykazały, że w analizowanym przez niego okresie wzrosła liczba próbek o niewłaściwej jakości handlowej, m.in. w grupach towarowych: ,pieczywo cukiernicze, ciasta i ciastka”, ,wyroby cukiernicze”, ,pieczywo”, ,drób i jego przetwory” oraz „mięso i jego przetwory" [Piwowar 2014, s. 94].

Porównanie jakości handlowej produktów żywnościowych w obiektach handlowych w latach 2012-2014 też wskazuje na pogorszenie się wskaźników. Kontrole IH 
Tabela 4. Przykłady kwestionowanego bezpieczeństwa produktów spożywczych w latach 2008-2014

\begin{tabular}{|c|l|}
\hline Rok & \multicolumn{1}{|c|}{ Informacje w mediach o dużym zasięgu publicznym (kraj) } \\
\hline 2008 & melamina w mleku w proszku dla niemowląt (Chiny) \\
\hline 2009 & mięso w puszkach sprzed 26 lat przeznaczone do spożycia (Polska) \\
\hline 2010 & kawa rozpuszczalna z drobinkami szkła (Polska) \\
\hline 2011 & $\begin{array}{l}\text { kiełki nasion kozieradki z bakteriami Escherichia coli - początkowo tzw. afera ogórkowa } \\
\text { (pochodzenie nasion - Egipt) }\end{array}$ \\
\hline 2012 & $\begin{array}{l}\text { sól drogowa w żywności (Polska) } \\
\text { ryby stemplowane nową datą przydatności do spożycia (Polska) } \\
\text { susz jajeczny zanieczyszczony mikrobiologicznie (Polska) }\end{array}$ \\
\hline 2013 & $\begin{array}{l}\text { trutka na gryzonie w mleku w proszku (Polska) } \\
\text { antybiotyki w hodowli drobiu (Polska) } \\
\text { larwy w czekoladkach (Polska) } \\
\text { konina w produktach z mięsa wołowego (lokalizacja nieustalona) } \\
\text { alkohol spożywczy z domieszką metanolu (Czechy) }\end{array}$ \\
\hline 2014 & \begin{tabular}{l} 
kaszki dla niemowląt zawierające niedopuszczalne alkaloidy (Niemcy) \\
\hline
\end{tabular} \\
\hline
\end{tabular}

Źródło: [Wierzejska 2015, s. 6].

przeprowadzone w 2014 r. spowodowały zakwestionowanie 27381 partii, tj. 19,8\%. (w 2013 r. - 17,1\%, w 2012 r. - 14,6\%), m.in. ze względu na:

1) wady jakości - 13,9\% partii (w 2013 r. - 9,5\%, w 2012 r. - 8,2\%),

2) nieprawidłowe oznakowanie - 21\% partii (w 2013 r. - 18,6\%, w 2012 r. $15,6 \%$ ),

3) niezgodną z deklarowaną zawartość netto - 1,2\% próbek (w 2013 r. - 1,1\%, w 2012 r. $-1,3 \%$ ),

4) przeterminowanie - 12,3\% partii (w 2013 r. - 10,3\%, w 2012r. - 9\%), przy czym partie zakwestionowane stanowiły często pojedyncze sztuki [UOKiK 2014, s. 36 ; UOKiK 2015, s. 33].

Wiele nieprawidłowości związanych z jakością żywności wykryła IH, badając produkty z tzw. najniższej półki cenowej. Takie badanie przeprowadzono po raz pierwszy w Polsce w 2014 r., a wyniki pokontrolne były bardzo niepokojące. We wstępie do raportu można przeczytać: „Postęp technologiczny oraz zwiększenie produkcji środków spożywczych przyniosły ze sobą skutki pozytywne w postaci większej dostępności żywności, ale z drugiej strony wpłynęło to negatywnie na jej jakość" [Raport. Jakość handlowa... 2014, s. 7]. Autorzy raportu zauważają, że metody produkcji i parametry jakościowe coraz częściej są narzucane przez wielkie koncerny. Tacy producenci traktują walory odżywcze produktów spożywczych jako sprawę drugorzędną, uznając, że konsumentów interesuje przede wszystkim niska cena. Skutkuje to tym, że żywność „,masowa” jest wytwarzana z użyciem wielu dozwolonych dodatków chemicznych, takich jak: barwniki, stabilizatory czy zagęstniki - stwierdzili autorzy raportu. Według IH przemysłowo wytwarzana żywność, dzięki swym niskim cenom, jest bardziej dostępna dla nabywców, jednak, spełniając 
wszystkie wymagania bezpieczeństwa, jakościowo niejednokrotnie pozostawia wiele do życzenia. IH zastrzega, że nie jest to reguła, która dotyczy wszystkiego, co jest tanie [Raport. Jakość handlowa... 2014, s. 7].

W zakończeniu raportu z badania produktów najtańszych IH stwierdziła, że do wyrobu najtańszych przetworów mięsnych używa się nieznacznych ilości mięsa, uzupełniając masę wodą oraz dozwolonymi, dodatkowymi substancjami chemicznymi, które zagęszczają tak powstały produkt. Ogólny wniosek z badania jest taki: „większość zbadanych wędlin i konserw charakteryzowała się niską zawartością mięsa w wyrobie gotowym, a także zdarzało się (tak jak w przypadku parówek i pasztetów), że w składzie w ogóle nie występowało mięso tylko mięso oddzielone mechanicznie (MOM) oraz szereg różnego rodzajów dodatków funkcjonalnych, które pozwalały na znaczne obniżenie kosztów produkcji poprzez podnoszenie pewnych parametrów fizykochemicznych, zwiększenie trwałości oraz nadanie produktom formy bardziej atrakcyjnej wizualnie" [Raport. Jakość handlowa... 2014, s. 34].

Poza tym w wyniku analiz laboratoryjnych mięsa stwierdzono m.in., że producenci dodawali tak małe jego ilości, że nie można go było wykryć w tych badaniach albo zadeklarowane na opakowaniu mięso w ogóle nie znajdowało się w wyrobie (dotyczyło to droższego mięsa wołowego). Badania laboratoryjne wykazywały również obecność w produkcie innych składników mięsnych (najczęściej tańszych, takich jak drobiowe), które były niewymienione w składzie podanym przez producenta [Raport. Jakość handlowa... 2014, s. 34].

Tabela 5. Najczęściej fałszowane produkty żywnościowe i rodzaj zafałszowania

\begin{tabular}{|c|l|l|}
\hline Lp. & \multicolumn{1}{|c|}{ Produkt } & \multicolumn{1}{|c|}{ Rodzaj zafałszowania } \\
\hline 1 & oliwa & $\begin{array}{l}\text { dodatek olejów roślinnych, mieszanie różnych gatunków oliwy, nieprawdziwe } \\
\text { dane o pochodzeniu }\end{array}$ \\
\hline 2 & olej roślinny & mieszanie olejów, nieprawdziwe dane o pochodzeniu \\
\hline 3 & miód & $\begin{array}{l}\text { dodatek sacharozy lub syropów cukrowych, mieszanie odmian miodów, } \\
\text { nieprawdziwe dane o pochodzeniu }\end{array}$ \\
\hline 4 & wino & $\begin{array}{l}\text { dodatek sacharozy lub syropów cukrowych, mieszanie win różnych odmian, } \\
\text { nieprawdziwe dane o pochodzeniu }\end{array}$ \\
\hline 5 & $\begin{array}{l}\text { whisky, } \\
\text { koniaki }\end{array}$ & $\begin{array}{l}\text { sokzi } \\
\text { pochodzeniu } \\
\text { dodatek sacharozy lub syropów cukrowych, mieszanie soków z różnych } \\
\text { owoców, dodatek wody, sok odtworzony zamiast soku naturalnego }\end{array}$ \\
\hline 7 & $\begin{array}{l}\text { kawa } \\
\text { Coffea canephora var. robusta zamiast Coffea arabica, nieprawdziwe dane } \\
\text { o pochodzeniu, niedeklarowany dodatek kawy zielonej do palonej, dodatek } \\
\text { upalonych surogatów do kawy mielonej, zamiast kawy kopi luwak inne gatunki }\end{array}$ \\
\hline 8 & herbata & $\begin{array}{l}\text { nieprawdziwe dane o jakości, nieprawdziwe dane o pochodzeniu } \\
\text { dodatek innych roślin, zmiany ilościowe i jakościowe w przyprawach, nadmierny } \\
\text { dodatek soli do przypraw }\end{array}$ \\
\hline 9
\end{tabular}

Źródło: opracowanie własne na podstawie [Śmiechowska 2013, s. 177]. 
Fakt fałszowania produktów żywnościowych jest kolejnym przejawem pogarszania się jakości żywności. Z rezultatów pokontrolnych badań wynika, że skala fałszowania żywności w ostatnich latach znacznie się zwiększyła. Tabela 5 zawiera zestawienie najczęściej fałszowanych produktów i rodzaje zafałszowania, którego dopuszczają się dostawcy wyrobów żywnościowych.

Żywność zafałszowana jest mniej wartościowa pod względem składu chemicznego i wartości odżywczych. Ponadto takie produkty mogą być szkodliwe dla zdrowia, a co niepokojące, wiedza konsumentów na temat zafałszowań żywności jest nikła w naszym kraju. Z badań A. Stój, K. Kwiecień i J. Mazurkiewicza wynika, że $85 \%$ ankietowanych nie słyszało $\mathrm{w}$ mediach informacji o produktach zafałszowanych [Stój, Kwiecień, Mazurkiewicz 2015, s. 318].

Z pokontrolnych informacji zamieszczonych w jednym z raportów IH z 2014 r. wynika, że bardzo dużo nieprawidłowości wykryto, badając poprawność oznakowania środków spożywczych dobrowolnymi informacjami, tj. takimi, których zamieszczenie na etykiecie nie jest obowiązkowe. Kontrola ta wykazała, że zakwestionowano 31,1\% zbadanych partii produktów ze względu na nierzetelność opisania danego produktu. W produktach, na których umieszczono napisy: „domowy”, „tradycyjny”, „wiejski', „,naturalny”, „,babuni”, „staropolski”, stwierdzono obecność licznych substancji dodatkowych (tj. dozwolonych dodatków do żywności oznaczonych symbolem E), które nie są stosowane w produkcji domowej i tradycyjnej. Na przykład: „polędwica tradycyjna, tradycyjne smaki” - według deklaracji na etykiecie zawierała, m.in. stabilizator trójpolifosforan sodu, wzmacniacz smaku: glutaminian sodu, dekstrozę, aromat dymu wędzarniczego, maltodekstrynę, regulator kwasowości: octan sodu, cytrynian sodu, przeciwutleniacz: askorbinian sodu, izoaskorbinian sodu, kwas askorbinowy, substancję konserwującą: azotyn sodu [Domowy, tradycyj$n y . . .2014$, s. 5]. Fałszowanie staje się naprawdę dużym problemem, który wymaga zdecydowanych środków zaradczych.

Nieprawidłowości zachodzące na rynku żywnościowym wymagają działań naprawczych. W polskim Narodowym programie zdrowia na lata 2007-2015, trzeci cel operacyjny dotyczył m.in. poprawy sposobu żywienia ludności i jakości zdrowotnej żywności [Narodowy program zdrowia..., s. 5]. Obecnie również cele europejskiej Wspólnej Polityki Rolnej skupiają się m.in. na poprawie jakości żywności. By rozwiązać problem braku wystarczającego poziomu jakości żywności, proponuje się wiele działań zaradczych. Wypada wspomnieć o Polskiej Normie i Znaku Zgodności z Polską Normą, która jest synonimem jakości i bezpieczeństwa. Warto, by organy i przedsiębiorcy nadzoru przypomnieli sobie o nich i powrócili do ich stosowania [Polska Norma... 2013, s. 86-88].

\section{Podsumowanie}

Dostęp do wystarczającej ilości żywności, bezpiecznej i odpowiedniej pod względem wartości odżywczych, ma kluczowe znaczenie dla życia i dobrego stanu zdrowia konsumentów. Wiedza konsumentów na ten temat jest coraz powszechniejsza, 
o czym świadczy choćby utożsamianie jakości żywności z jej zdrowotnością. Podstawowym celem wszystkich regulacji prawnych dotyczących żywności jest ochrona zdrowia konsumenta. Konsument ma bowiem prawo do żywności bezpiecznej.

Najważniejszym wnioskiem $\mathrm{z}$ analiz przeprowadzonych w artykule jest to, że trudno jednoznacznie ocenić poziom jakości i bezpieczeństwa żywności. Z jednej strony następuje poprawa jakości zdrowotnej żywności, co jest efektem poprawy stanu sanitarno-higienicznego obiektów. Ogólnie znane jest wszystkim przeświadczenie o wysokiej jakości polskiej żywności i na tę cechę wskazują też niektóre pokontrolne sprawozdania. Niestety, nie dotyczy to wszystkich produktów żywnościowych. $Z$ rynku płyną również sygnały świadczące o nieprawidłowościach w jakości handlowej, z którymi stykają się konsumenci, a są nimi tzw. afery żywnościowe czy proceder fałszowania żywności. Często konsumenci żywności mają przeświadczenie, że żywność w naszym kraju ma niską jakość. Nadal zatem jest wiele do zrobienia w kwestii poprawy ogólnego poziomu jakości żywności w Polsce. W związku z tym instytucje kontrolne powinny systematycznie monitorować jakość produktów tanich, bo wśród tej grupy produktów jest bardzo dużo nieprawidłowości. Proceder fałszowania żywności należy wyeliminować, surowo karząc uczestniczących w nim przedsiębiorców. Ustalenie odpowiedniej wysokości kar za różnego rodzaju nieprawidłowości, stanowią temat do rozważań w kolejnym artykule.

\section{Literatura}

Bezpieczeństwo żywności [panel ekspertów], 2015, https://www.nik.gov.pl/aktualnosci/bezpieczenstwo-zywnosci-panel-ekspertow.html, 19.08.2015.

Cianciara D., 2011, Społeczny wymiar żywienia - zadania dla promocji zdrowia $w$ Polsce, Hygeia Public Health, 46 (1), s. 21-24.

Ćwiek P., Oszukana żywność, http://m.onet.pl/wiedza-swiat/nauka,rjsxx, 29.10.2013.

Departament Inspekcji Handlowej UOKiK, 2014a, Domowy, tradycyjny, naturalny, bez konserwantów, bez barwników, bez sztucznych stodzików, wolny od GMO: kontrola Inspekcji Handlowej, Warszawa.

Departament Inspekcji Handlowej UOKiK, 2014b, Jakość handlowa najtańszych produktów mięsnych i mlecznych w świetle kontroli przeprowadzanych przez Inspekcję Handlowa, Raport, Warszawa.

Domowy, tradycyjny, naturalny, bez konserwantów, bez barwników, bez sztucznych słodzików, wolny od GMO: kontrola Inspekcji Handlowej, 2014, Departament Inspekcji Handlowej UOKiK, Warszawa, grudzień.

Główny Inspektorat Sanitarny, PIS, 2008, Stan sanitarny kraju 2007, Warszawa.

Główny Inspektorat Sanitarny, PIS, 2010, Stan sanitarny kraju za 2009 rok, Warszawa.

Główny Inspektorat Sanitarny, PIS, 2015, Stan sanitarny kraju w roku 2014, Warszawa.

Główny Inspektorat Sanitarny, PIS, 2016, Stan sanitarny kraju w roku 2015, Warszawa.

Gulbicka B., 2008, Polskie prawo żywnościowe, Biuletyn Informacyjny ARR, Agencja Rynku Rolnego, Warszawa, nr 12, s. 45-58.

Jakość polskiej żywności i działania Państwowej Inspekcji Sanitarnej. Rozmowa z Markiem Posobkiewiczem - Głównym Inspektorem Sanitarnym, 2014, FOOD Lex, nr 3, s. 8-11.

Jeżewska-Zychowicz M., Babicz-Zielińska E., Laskowski W., 2009, Konsument na rynku nowej żywności. Wybrane uwarunkowania spożycia, Wydawnictwo SGGW, Warszawa. 
Juchniewicz M., 2008, Jakość jako czynnik wzrostu konkurencyjności przemystu spożywczego w Polsce, [w:] Wybrane aspekty konkurencyjności producentów żywności, (red.) J. Szczepaniak, IERiGŻ PIB, Warszawa, nr 110.

Kowrygo B., Rejman K., Drozdowska A., 2015, Zachowania nabywcze w zakresie żywności klientów sieci Biedronka i postrzeganie jej placówek sprzedaży, Handel Wewnętrzny, nr 2 (355), s. 209-221.

Majchrzak B., 2013, Jakość handlowa wędlin w Polsce na podstawie wyników kontroli IJHARS w latach 2009-2013, Wiedza i Jakość, nr 33(5), s.6-8.

Meredyk K., 2014., Wstęp, [w:] Mechanizm rozwoju sektora żywnościowego, Meredyk K. (red.), WSFiZ, Białystok.

Morkis G., 2014, Systemy zarządzania bezpieczeństwem i jakościa żywności w przemyśle spożywczym w Polsce, Roczniki Naukowe Stowarzyszenia Ekonomistów Rolnictwa i Agrobiznesu, t. XVI, z. 6, Warszawa - Poznań - Lublin, s. 366-370.

MRiRW, 2016, Informacja o założeniach reformy systemu bezpieczeństwa żywności, Biuro Prasowe, Warszawa.

Narodowy program zdrowia na lata 2007-2015, Załącznik do Uchwały Nr 90/2007 Rady Ministrów $\mathrm{z}$ dnia 15 maja $2007 \mathrm{r}$.

NIK o rolnictwie ekologicznym, 2010, https://www.nik.gov.p1/aktualnosci/nik-o-rolnictwie-ekologicznym.html, 30.03.2010.

Ozimek I., 2007, Jakość żywności w opinii konsumentów, Handel Wewnętrzny, nr 1, s. 47-53.

Piwowar A., 2014, Jakość handlowa wybranych grup towarowych artykułów rolno-spożywczych $w$ Polsce, Nauki Inżynierskie i Technologie, nr 2 (13), s. 88-97.

Polska Norma - synonim jakości i bezpieczeństwa. Rozmowa z Anna Stankowska, Dyrektorem Wydziatu Certyfikacji w Polskim Komitecie Normalizacyjnym, 2013, Bezpieczeństwo i Higiena Żywności, 02/109, s. 86-88.

Racje i emocje. Rzecz o bezpieczeństwie żywności. Rozmowa z dr. Jarosławem Naze, zastępca Lekarza weterynarii ds. Bezpieczeństwa żywności pochodzenia zwierzęcego oraz pasz, farmacji i utylizacji, 2015, Biuletyn Informacyjny ARR, ARR, nr 3, s. 12-15.

Raport. Jakość handlowa najtańszych produktów mięsnych i mlecznych w świetle kontroli przeprowadzanych przez Inspekcję Handlowa, 2014, Departament Inspekcji Handlowej UOKiK, Warszawa, grudzień.

Rozporządzenie Prezydenta Rzeczypospolitej z dnia 22 marca 1928 r. o dozorze nad artykułami żywności i przedmiotami użytku (Dz.U. $1928 \mathrm{nr}$ 36, poz. 343).

Staniak S., 2014, Charakterystyka żywności produkowanej w warunkach rolnictwa ekologicznego, Polish Journal of Agronomy, no. 19, s. 25-35.

Stan sanitarny kraju 2007, 2008, Główny Inspektorat Sanitarny, PIS, Warszawa.

Stan sanitarny kraju w roku 2014, 2015, Główny Inspektorat Sanitarny, PIS, Warszawa.

Stan sanitarny kraju w roku 2015, 2016, Główny Inspektorat Sanitarny, PIS, Warszawa.

Stan sanitarny kraju za 2009 rok, 2010, Główny Inspektorat Sanitarny, PIS, Warszawa.

Stój A., Kwiecień K., Mazurkiewicz J., 2015, Wiedza konsumentów na temat zafatszowań żywności, [w:] Bezpieczeństwo zdrowotne żywności. Aspekty mikrobiologiczne, chemiczne i ocena towaroznawcza, Stadnik J., Jackowska I. (red.), Wydawnictwo Naukowe PTTŻ, Kraków, s. 309-320.

Śmiechowska M., 2013, Autentyczność jako kryterium zapewnienia jakości żywności, Ann. Acad. Med. Gedan, t. 43, s. 175-181.

UOKIK, 2014, Sprawozdanie z działalności Inspekcji Handlowej w 2013 roku, Warszawa.

UOKIK, 2015, Sprawozdanie z działalności Inspekcji Handlowej w 2014 roku, Warszawa.

Wierzejska R., 2015, Bezpieczeństwo żywności w Polsce w okresie członkowstwa w Unii Europejskiej, Przemysł Spożywczy, luty, t. 69(2), s. 2-6.

Zalega T., 2014, Zachowania konsumpcyjne polskich gospodarstw domowych w okresie II fali kryzysu, Handel Wewnętrzny, nr 4, s. 40-53. 